\title{
Vasorelaxant mechanisms of ketamine in rabbit renal artery
}

\author{
Il Jung and Sung Hwan Jung \\ Department of Anesthesiology and Pain Medicine, Gangneung Asan Hospital, University of Ulsan College of Medicine, Gangneung, \\ Korea
}

Background: Ketamine is a non-barbiturate anesthetic agent which has various effects on the cardiovascular system. Among them, ketamine is known for its hypotensive properties. The hypotension is thought to be mediated by a direct effect on vascular smooth muscles. This study is designed to examine the effects of ketamine on KCl- and histamine-induced contraction in isolated rabbit renal arteries.

Methods: Endothelium-intact or -denuded smooth muscle rings were prepared and mounted in myographs for isometric tension measurements. The inhibitory effect of ketamine were investigated in smooth muscle rings precontracted with either $50 \mathrm{mM} \mathrm{KCl}$ - or $10 \mu \mathrm{M}$ histamine.

Results: Ketamine $(0.1-100 \mu \mathrm{g} / \mathrm{ml})$ produced similar concentration-dependent inhibition of contractile responses induced by either $50 \mathrm{mM} \mathrm{KCl}$ or $10 \mu \mathrm{M}$ histamine. The respective $\mathrm{IC}_{50}$ values measured for ketamine following precontractions by $50 \mathrm{mM} \mathrm{KCl}$ and $10 \mu \mathrm{M}$ histamine were $28.9 \mu \mathrm{g} / \mathrm{ml}(105.5 \mu \mathrm{M})$ and $26.7 \mu \mathrm{g} / \mathrm{ml}(97.5 \mu \mathrm{M})$. The inhibitory effect of $30 \mu \mathrm{g} / \mathrm{ml}$ ketamine were similarly observed after removal of endothelium or pretreatment with $\mathrm{N}^{\mathrm{G}}$-Nitroarginine Methyl Ester $(0.1 \mathrm{mM})$. The inhibitory effect of $30 \mu \mathrm{g} / \mathrm{ml}$ ketamine on histamine-evoked contraction was reduced by either tetraethylammonium $(10 \mathrm{mM})$ or iberiotoxin, a large conductance $\mathrm{Ca}^{2+}$-activated $\mathrm{K}^{+}$channel blocker. However, depletion of intracellular $\mathrm{Ca}^{2+}$ stores by ryanodine $(10 \mu \mathrm{M})$ or thapsigargin $(10 \mu \mathrm{M})$ showed no significant effect on $30 \mu \mathrm{g} / \mathrm{ml}$ ketamine-induced relaxation. Pre-incubation with $30 \mu \mathrm{g} / \mathrm{ml}$ ketamine significantly inhibited $\mathrm{CaCl}_{2}$-induced contraction at almost all ranges of concentration.

Conclusions: Ketamine-induced relaxation of rabbit renal arteries is mediated by both the activation of large conductance $\mathrm{Ca}^{2+}$-activated $\mathrm{K}^{+}$channel and the inhibition of $\mathrm{Ca}^{2+}$ influx. (Korean J Anesthesiol 2012; 63: 533-539)

Key Words: $\mathrm{Ca}^{2+}$ influx, Ketamine, Potassium channel, Rabbit renal artery, Relaxation.

\footnotetext{
Received: February 3, 2012. Revised: 1st, June 1, 2012; 2nd, July 19, 2012; 3rd, August 20, 2012; 4th, September 4, 2012. Accepted: September 4, 2012. Corresponding author: Il Jung, M.D., Ph.D., Department of Anesthesiology and Pain Medicine, Gangneung Asan Hospital, University of Ulsan College of Medicine, Bangdong-ri Sacheon-myeon, Gangneung 210-711, Korea. Tel: 82-33-610-3408, Fax: 82-33-641-8180, E-mail: tourji9@ naver.com

(c) This is an open-access article distributed under the terms of the Creative Commons Attribution Non-Commercial License (http:// creativecommons.org/licenses/by-nc/3.0/), which permits unrestricted non-commercial use, distribution, and reproduction in any medium, provided the original work is properly cited.
} 


\section{Introduction}

Ketamine is a general anesthetic which has been reported to have a variety of cardiovascular effects: alteration of systemic arterial pressure with significant increases in heart rate, cardiac output, cardiac work and mediating myocardial oxygen requirements in normal humans with hypertensive properties. The mechanisms of these hypertensive actions are complex and thought to be via the central sympathetic nervous system [1]. Some studies also suggested that ketamine induces systemic hypotension and significantly alters distribution of blood flow to various organs $[2,3]$.

The mechanism of this cardiovascular effect is not clear, but it seems to be mediated by the changes in vascular tone through its direct action on vascular smooth muscle and/or endothelium [2-5]. It has been demonstrated that ketamine causes relaxation of vascular smooth muscle tone in a endothelium-dependent manner [4]. Therefore Lee and Hou [5] proposed that in endothelium-intact tissues, the direct action of ketamine on pulmonary arteries may not contribute to systemic hypotension during ketamine anesthesia. However in the absence of endothelium, contractile responses to norepinephrine and $\mathrm{KCl}$ were both inhibited during exposure to ketamine [4]. Thus, we speculated that in endothelium-denuded tissues, the direct inhibitory action of ketamine on mesenteric arterial smooth muscle cells may contribute to systemic hypotension during ketamine anesthesia [4]. The mechanism underlying the ketamine-induced vasorelaxation is supposed to be the increase in $\mathrm{K}^{+}$conductance or the decrease in cytosolic $\mathrm{Ca}^{2+}$ levels $\left(\left[\mathrm{Ca}^{2+}\right]_{\text {cyt }}\right)[6,7]$. The contribution of $\mathrm{K}^{+}$channels to ketamine-induced relaxation appears to be dependent on tissue sources, and species and agonist employed to induce vasorelaxation $[6,8]$. The rise in $\left[\mathrm{Ca}^{2+}\right]_{\text {cyt }}$ is an important determinant in contractions of vascular smooth muscle [9]. Previous studies on vascular smooth muscle have suggested that the direct inhibitory action of intravenous anesthetics is a result of both reduction of $\left[\mathrm{Ca}^{2+}\right]_{\mathrm{cyt}}$ and inhibition of the myofilament $\mathrm{Ca}^{2+}$ sensitivity $[10,11]$. Furthermore, ketamine was reported to inhibit $\mathrm{Ca}^{2+}$ influx through L-type $\mathrm{Ca}^{2+}$ channels elicited by acetylcholine [7]. Therefore, it is possible that modulation of smooth muscle contraction by ketamine is due to the decrease in $\left[\mathrm{Ca}^{2+}\right]_{\text {cyt }}$.

Based on previous studies, it is suggested that the effect and action mechanism of intravenous anesthetics may vary in potency or even in quality with different vascular tissues or even with different segments of the same artery. Considerable evidence also shows that propofol and ketamine induced hemodynamic changes but did not significantly affect renal blood flow [11-14]. Maintenance of renal blood flow may be important in clinical situations during intravenous anesthesia. Therefore it is necessary to know how ketamine affects responses of the renal artery to vasoconstrictors both in vivo and in vitro. However, less information is available regarding the effects of ketamine on renal smooth muscle. The aims of this study were designed to determine the effects of $\mathrm{K}^{+}$channel blockers and $\mathrm{Ca}^{2+}$ store inhibitors on ketamine-induced relaxations in isolated rabbit renal arteries. We also test the hypothesis that the inhibitory effect of ketamine involved a decrease in influx of extracellular calcium.

\section{Materials and Methods}

\section{Experimental preparations}

All experimental procedures and protocols were approved by the Institutional Animal Care and Use Committee. Tension experiments were performed according to the method described. Fifty-five New Zealand white rabbits $(2-3 \mathrm{~kg})$ of either sex were killed by exsanguination after anesthesia with pentobarbital sodium (30 mg/kg, iv). The renal arteries were quickly excised and placed in a cold Krebs solution. The vessels were cut into $1 \mathrm{~mm}$-wide ring segments and were placed in 3 $\mathrm{ml}$ tissue baths on $2 \mathrm{~L}$-shaped hooks, one of which was attached to a force transducer for isometric measurement of tension. The vessel tension was recorded on a pen recorder. Before starting the experiments, the resting tension of $1 \mathrm{~g}$ was maintained throughout the experiments. Tissues were allowed to equilibrate for $90 \mathrm{~min}$ before each experiment.

The function of the endothelium was checked at the beginning of each experiment with acetylcholine (ACh). More than $50 \%$ of endothelium-intact, $1 \mu \mathrm{M}$ norepinephrine-precontracted rings responding to $\mathrm{ACh}(1 \mu \mathrm{M})$ by relaxation were considered to have functionally intact endothelium and were accepted for further study. In some experiments, the endothelium was mechanically removed by gentle rubbing with moistened cotton, and its absence was confirmed by the lack of a relaxant response to ACh. Unless otherwise stated, L-N ${ }^{\mathrm{G}}$-Nitroarginine Methyl Ester (L-NAME, $0.1 \mathrm{mM}$ ) was present in the physiological salt solution (PSS).

The contractile response induced by isotonic $50 \mathrm{mM} \mathrm{KCl}$ was measured for all renal arterial rings and used as a reference value (100\%). After washing out the $\mathrm{KCl}$ from the organ bath and returning the isometric tension to the baseline resting tension, relaxations were studied in preparations contracted by either $50 \mathrm{mM} \mathrm{KCl}$ - or $10 \mu \mathrm{M}$ histamine. When stable contractions were obtained, ketamine were added cumulatively to determine the concentration-response relationship. Each ring was used for only one ketamine concentration-response curve. The concentrations of ketamine used in these experiments were $0.1-100 \mu \mathrm{g} / \mathrm{ml}$. The obtained $\mathrm{IC}_{50}$ values measured for ketamine following precontractions by $50 \mathrm{mM} \mathrm{KCl}$ and $10 \mu \mathrm{M}$ histamine 
were $28.9 \mu \mathrm{g} / \mathrm{ml}$ and $26.7 \mu \mathrm{g} / \mathrm{ml}$, respectively. Therefore we used $30 \mu \mathrm{g} / \mathrm{ml}$ ketamine $(30 \mu \mathrm{g} / \mathrm{ml})$ in the following experiments.

To investigate the effect of L-NAME $(0.1 \mathrm{mM}), \mathrm{K}^{+}$channel blockers and $\mathrm{Ca}^{2+}$ store inhibitors on ketamine-induced relaxations, renal arteries were precontracted with $10 \mu \mathrm{M}$ histamine. Relaxation response to ketamine was calculated as percentage of the precontracted value; the stabilized tension after precontraction was determined as $100 \%$ and the baseline tension before precontraction as $0 \%$. After washout with PSS, incubation with either L-NAME $(0.1 \mathrm{mM}), \mathrm{K}^{+}$channel blockers or $\mathrm{Ca}^{2+}$ store inhibitors was carried out for $30 \mathrm{~min}$. The relaxing effect of ketamine was investigated in the absence and presence of either L-NAME (0.1 mM), $\mathrm{K}^{+}$channel blockers or $\mathrm{Ca}^{2+}$ store inhibitors. In separate experiments with endothelium removed tissue, responses to histamine and ketamine were repeated again and then compared with endothelium-intact tissue.

To investigate the $\mathrm{Ca}^{2+}$ channel antagonistic effect of ketamine, concentration-response curves to $\mathrm{CaCl}_{2}(0.003-3$ $\mathrm{mM}$ ) were obtained in the absence and presence of ketamine (30 $\mu \mathrm{g} / \mathrm{ml}$ ). After renal artery rings were allowed to equilibrate for $30 \mathrm{~min}$ the rings were washed three times at 10-min intervals with $\mathrm{Ca}^{2+}$-free PSS which containing ethylene glycol bis ( $\beta$-aminoethyl ether)-N,N,N,N,--tetraacetic acid (EGTA, $1 \mathrm{mM}$ ). The rings were then bathed with $\mathrm{Ca}^{2+}$-free, high $\mathrm{K}^{+}(50 \mathrm{mM})$ PSS with or without ketamine. After the rings were incubated with ketamine for $30 \mathrm{~min}$, the concentration-response curves to $\mathrm{CaCl}_{2}$ were constructed. The concentration-response curves of $\mathrm{CaCl}_{2}$ were compared by repeated measures analysis to assess the effect of ketamine.

\section{Solutions}

The composition of Krebs solution was as follows (in $\mathrm{mM}$ ): $\mathrm{NaCl}$ 136.9, $\mathrm{KCl} 5.4, \mathrm{CaCl}_{2} 1.5, \mathrm{MgCl}_{2} 1.2, \mathrm{NaHCO}_{3}$ 23.8, Ethylenediaminetetraacetic acid (EDTA) 0.01, glucose 5.5. EDTA was added to chelate the contaminated heavy metal ions. It was saturated with $95 \% \mathrm{O}_{2}$ and $5 \% \mathrm{CO}_{2}$ gas mixture at $37^{\circ} \mathrm{C}$ to maintain $\mathrm{pH}$ at 7.4. The isotonic $50 \mathrm{mM} \mathrm{KCl}$ solution was prepared by replacing $\mathrm{NaCl}$ with an equimolar amount of $\mathrm{KCl}$. In $\mathrm{Ca}^{2+}$-free solutions, $\mathrm{CaCl}_{2}$ was replaced with $\mathrm{MgCl}_{2}$.

\section{Drugs}

Drugs used in this study were acetylcholine chloride, 4-aminopyridine (4-AP), EGTA, histamine dihydrochloride, iberiotoxin, ketamine hydrochloride, L,-NAME, norepinephrine hydrochloride, potassium chloride and tetraethylammonium (TEA) (Sigma, USA), ryanodine and thapsigargin (Calbiochem, USA), glibencamide (Tocris, UK).

\section{Data analysis}

Results were expressed as mean \pm SEM. The number of preparations taken from separate animals was indicated by $\mathrm{n}$. A one-way repeated-measurements of analysis of variance followed by Scheffe's F test for post hoc analysis, as well as paired t tests were used for the statistical analysis (Prism 5.0, GraphPad software, San Diego, CA, USA). P values of less than $5 \%(\mathrm{P}<0.05)$ were considered statistically significant.

\section{Results}

\section{Effects of ketamine on $\mathrm{KCl}$ - and histamine-induced contractions}

$50 \mathrm{mM} \mathrm{KCl}$ and $10 \mu \mathrm{M}$ histamine produced approximately the same amplitude of contraction, and we investigated the effects of ketamine on these similar contractions. In the endothelium-intact ring segments of rabbit renal arteries precontracted with either $50 \mathrm{mM} \mathrm{KCl}$ or $10 \mu \mathrm{M}$ histamine, ketamine $(0.1-100 \mu \mathrm{g} / \mathrm{ml})$ induced a concentration-dependent relaxation ( $\mathrm{n}=8$, Fig. 1 ). The obtained $\mathrm{IC}_{50}$ values measured for $50 \mathrm{mM} \mathrm{KCl}$ - and $10 \mu \mathrm{M}$ histamine were $28.9 \mu \mathrm{g} / \mathrm{ml}(105.5 \mu \mathrm{M})$ and $26.7 \mu \mathrm{g} / \mathrm{ml}(97.5 \mu \mathrm{M})$, respectively. In these experiments, treatment with $30 \mu \mathrm{g} / \mathrm{ml}$ ketamine significantly inhibited the histamine-induced contractions $(54.3 \pm 4.8, \mathrm{n}=8)$. Therefore we used $30 \mu \mathrm{g} / \mathrm{ml}$ ketamine $(30 \mu \mathrm{g} / \mathrm{ml})$ in the following experiments.

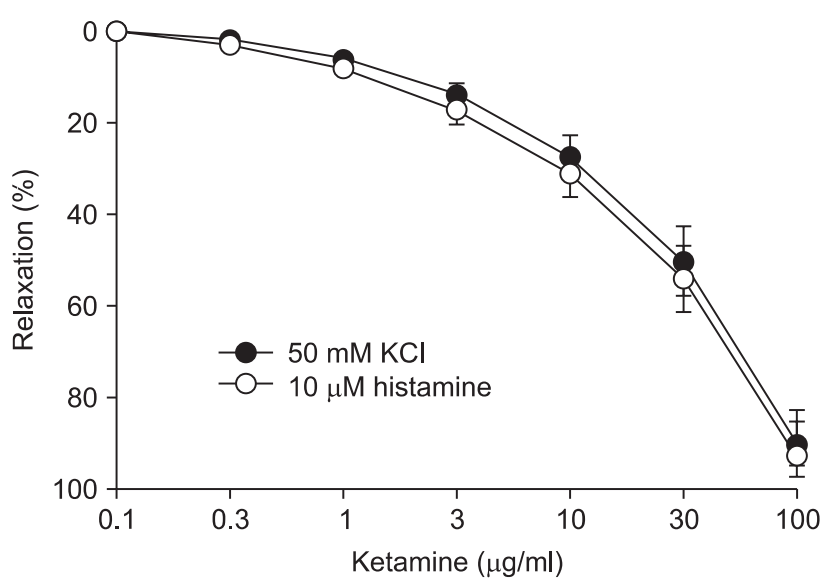

Fig. 1. Average concentration-response curves for the relaxant effects of ketamine on contraction induced by $50 \mathrm{mM} \mathrm{KCl}(\bigcirc)$ and $10 \mu \mathrm{M}$ histamine $(\bigcirc)$. Ketamine $(0.1-100 \mu \mathrm{l} / \mathrm{ml})$ was cumulatively added after the contraction reached a steady state. Responses are expressed as the percentage of contraction elicited by either $50 \mathrm{mM} \mathrm{KCl}$ or 10 $\mu \mathrm{M}$ histamine before addition of ketamine. Each point represents the mean of 8 rings and SEM is shown by vertical bar. 


\section{Effects of nitric oxide on ketamine-induced relaxation}

Typical recordings of the response to ketamine in renal arterial rings with endothelium are shown in Fig. 2A. The addition of $10 \mu \mathrm{M}$ histamine induced a sustained increase in muscle tension. Ketamine $(30 \mu \mathrm{g} / \mathrm{ml})$, administered after histamine-evoked contraction reached a steady state, and elicited a sustained decrease in muscle tension. Ketamineinduced relaxation was not affected either by L-NAME (0.1 $\mathrm{mM}$ ), nitric oxide (NO) synthase blocker, or by mechanical removal of the endothelium $(n=6)$, suggesting that ketamineinduced vasorelaxation was not mediated by NO (Control: 63.3 $\pm 6.5 \%$, L-NAME: $59.3 \pm 6.1 \%$, and endothelium removal $67.4 \pm$ $6.1 \%, \mathrm{n}=6$ ) (Fig. 2B).

A
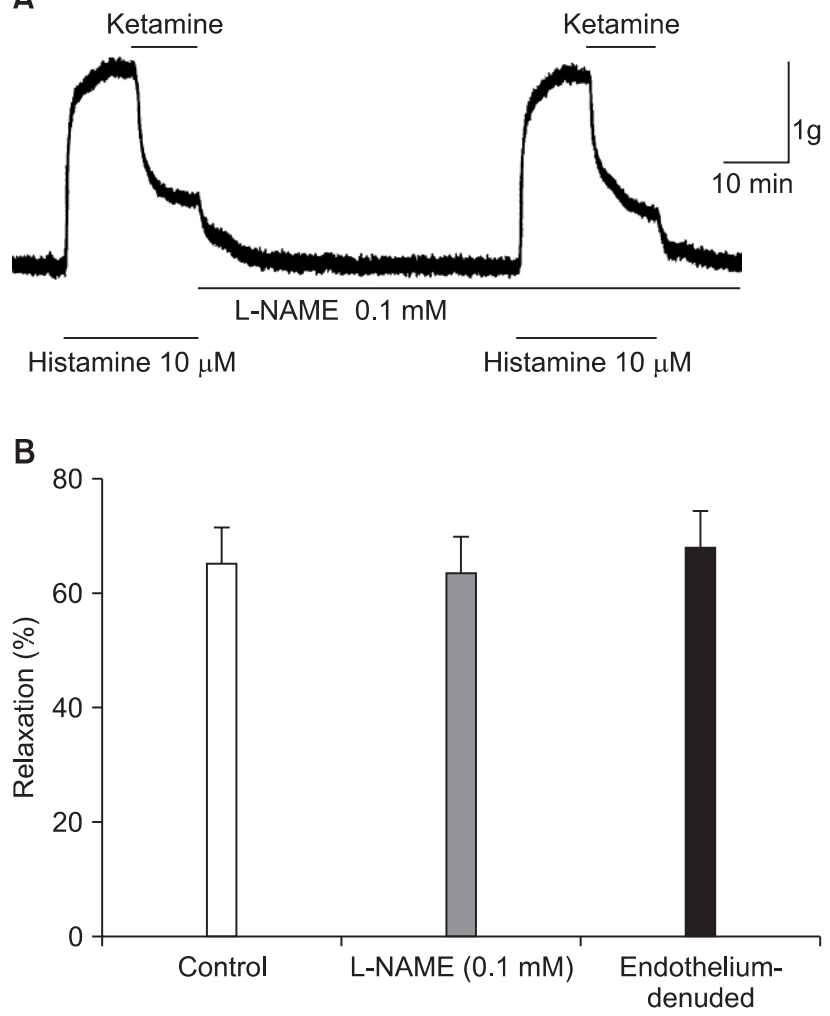

Fig. 2. (A) Typical recordings showing the effects of $\mathrm{L}-\mathrm{N}^{\mathrm{G}}$-Nitroarginine Methyl Ester (L-NAME), nitric oxide synthase blocker, on ketamine $(30 \mu \mathrm{g} / \mathrm{ml})$-induced relaxation in a rabbit renal artery precontracted with $10 \mu \mathrm{M}$ histamine. Original tracing show the ketamine-induced relaxation in the absence and presence of L-NAME $(0.1 \mathrm{mM})$. (B) Summarized data showing the effect of L-NAME or endothelium removal on histamine-evoked contraction. Columns which are the mean \pm SEM from 6 separate experiments, represent the effects of under control conditions (Control) and in the presence of L-NAME or the condition of endothelium removal.

\section{Effects of $\mathrm{K}^{+}$channels blockers on ketamine-induced relaxation}

The contribution of $\mathrm{K}^{+}$channels to ketamine-induced relaxation was assessed in the renal artery precontracted with $10 \mu \mathrm{M}$ histamine. Ketamine-induced relaxation was significantly inhibited by either TEA (10 mM), non-specific $\mathrm{K}^{+}$channel blocker, or by iberiotoxin $(0.1 \mu \mathrm{M})$, an inhibitor of large conductance $\mathrm{Ca}^{2+}$-activated $\mathrm{K}^{+}$channels (Control: $65.2 \pm 5.8 \%$, TEA: $47.8 \pm 4.6 \%$, and iberiotoxin $43.3 \pm 4.5 \%, \mathrm{n}=6$ ) (Fig. 3 ). In contrast to the effects of large conductance $\mathrm{Ca}^{2+}$-activated $\mathrm{K}^{+}$ channels blockers, either glibenclamide $(10 \mu \mathrm{M})$, the inhibitor of ATP-sensitive $\mathrm{K}^{+}$channels or 4 -AP $(5 \mathrm{mM})$, a putative inhibitor of delayed rectifier $\mathrm{K}^{+}$channel did not affect the relaxation to ketamine (Control, glibenclamide: $64.8 \pm 6.1 \%$, and 4 -AP: $61.2 \pm 5.9 \%, \mathrm{n}=6)$.

\section{Effects of $\mathrm{Ca}^{2+}$ store inhibitors on ketamine-induced relaxation}

The possible involvement of $\mathrm{Ca}^{2+}$ store to ketamine-induced relaxations were assessed with thapsigargin or ryanodine in the rabbit renal artery precontracted with histamine $(10 \mu \mathrm{M})$. Ketamine-induced relaxation was not inhibited following inhibition of $\mathrm{Ca}^{2+}$ release from sarcoplasmic reticulim with ryanodine $(10 \mu \mathrm{M})$ or endoplasmic reticulum $\mathrm{Ca}^{2+}$-ATPase

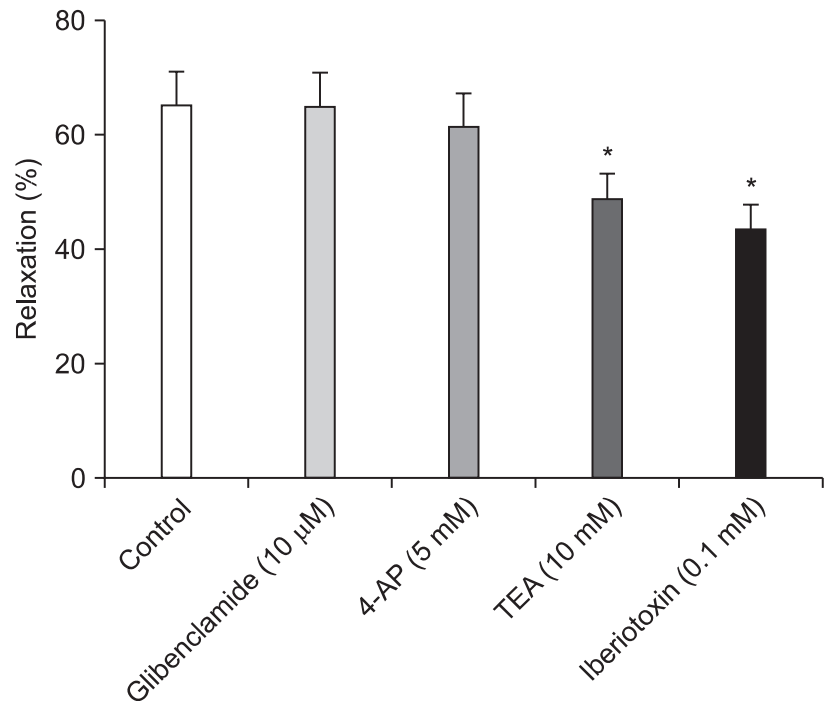

Fig. 3. Summarized data showing the inhibitory effects of $\mathrm{K}^{+}$channel blockers on ketamine $(30 \mu \mathrm{g} / \mathrm{ml})$-induced relaxation. Columns which are the mean \pm SEM from 6 separate experiments, represent the effects of under control conditions (Control) and in the presence of glibenclamide $(10 \mu \mathrm{M}), 4$-aminopyridine $(5 \mathrm{mM})$, tetraethylammonium $(10 \mathrm{mM})$ or iberiotoxin $(0.1 \mu \mathrm{M}) . * \mathrm{P}<0.05$, versus control (paired t-test). 


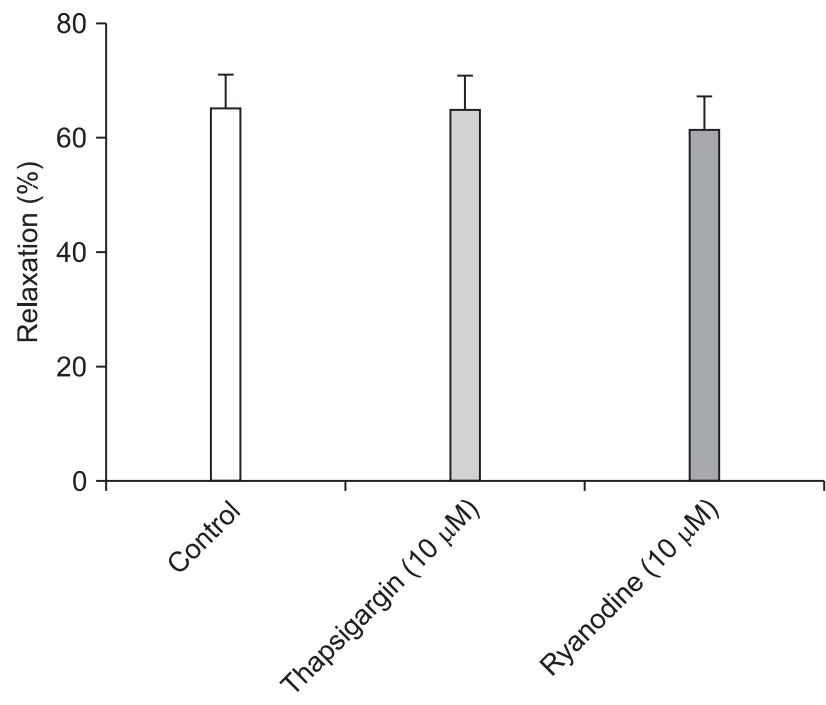

Fig. 4. Summarized data showing the inhibitory effects of thapsigargin $(10 \mu \mathrm{M})$ and ryanodine $(10 \mu \mathrm{M})$ on ketamine $(30 \mu \mathrm{g} / \mathrm{ml})$ induced relaxation. Columns which are the mean \pm SE mean from 5 separate experiments, represent the effects of under control conditions (Control) and in the presence of thapsigargin $(10 \mu \mathrm{M})$ or ryanodine $(10 \mu \mathrm{M})$.

pathway with thapsigargin $(10 \mu \mathrm{M})$ (Control: $66.8 \pm 6.0 \%$, thapsigargin: $59.7 \pm 5.5 \%$, and ryanodine: $57.3 \pm 4.8 \%, \mathrm{n}=5$ ) (Fig. 4).

\section{Effects of ketamine on $\mathrm{Ca}^{2+}$-induced contraction}

In rings depolarized with $50 \mathrm{mM} \mathrm{KCl}$ solution in a $\mathrm{Ca}^{2+}$-free medium, the addition of cumulative addition of $\mathrm{CaCl}_{2}(0.003-$ $3 \mathrm{mM}$ ) induced concentration-dependent contractions $(\mathrm{n}=5$, Fig. 5A).

Pretreatment with $30 \mu \mathrm{g} / \mathrm{ml}$ ketamine slightly reduced basal tension and strongly inhibited $\mathrm{CaCl}_{2}$-induced contraction ( $\mathrm{n}=5$, Fig. 5B).

\section{Discussion}

When a ketamine-involved anesthesia is performed, maintenance of renal blood flow is important in many clinical situations [15]. So, it is necessary to know how ketamine affects responses of the renal artery to vasoconstrictors like histamine and $\mathrm{KCl}$. If the histamine- or KCl-evoked contraction of the renal artery takes place, it is important that ketamine-induced relaxation of the renal artery may affect or not affect renal blood flow and urine output.

Our finding clearly indicate that endothelium-independent relaxation induced by ketamine in rabbit renal arteries involves both activation of large conductance $\mathrm{Ca}^{2+}$-activated of $\mathrm{K}^{+}$ channels ( $\mathrm{BK}_{\mathrm{Ca}}$ channels) and inhibition of $\mathrm{Ca}^{2+}$ influx. Ketamine induced a concentration-dependent relaxation, which was
A

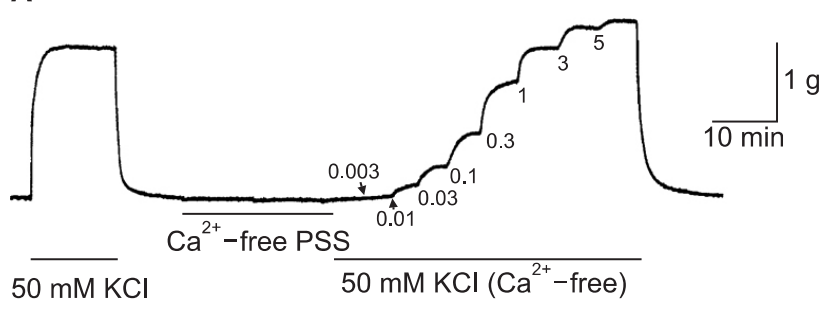

B

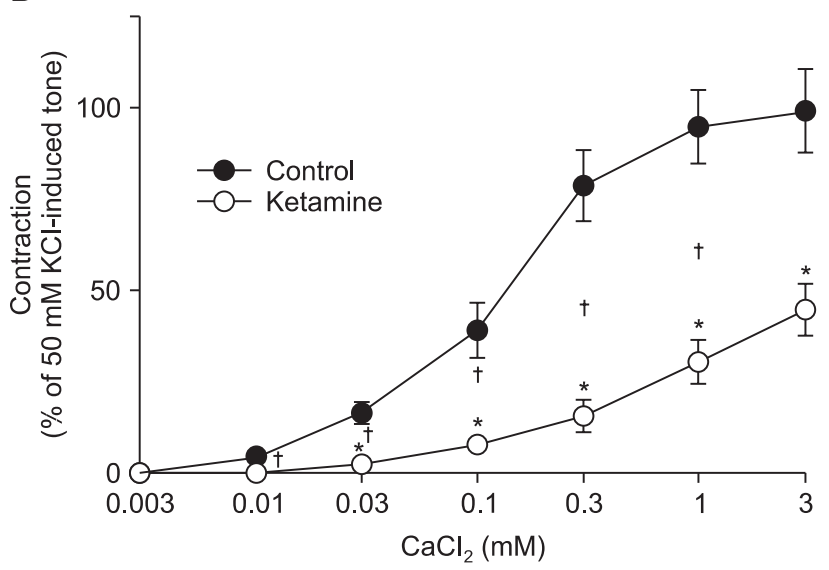

Fig. 5. Traces showing ketamine $(30 \mu \mathrm{g} / \mathrm{ml})$-induced relaxation in rabbit renal arteries contracted by $50 \mathrm{mM} \mathrm{KCl}$ in the absence (O) and presence $(\bigcirc$ ) of ketamine (A). 100\% represents the $50 \mathrm{mM} \mathrm{KCl}$ induced sustained increase in force before washout. Each point represents the mean of 5 rings and SEM is shown by vertical bar. *P < 0.05 , versus control (paired t-test). ${ }^{\dagger} \mathrm{P}<0.05$, versus control (ANOVA followed by Scheffe's F test for post hoc analysis).

not affected either by removal of endothelium or by L-NAME. These results suggested that ketamine-induced relaxation of the rabbit renal artery is endothelium-independent and rules out an involvement of NO in the relaxation responses to ketamine, suggesting that ketamine may directly act on vascular smooth muscle.

The cellular mechanism underlying ketamine-mediated relaxation of vascular smooth muscle is not fully understood, although opening of some $\mathrm{K}^{+}$channels and inhibition of $\mathrm{Ca}^{2+}$ availability have been suggested as being involved in the relaxation of intravenous anesthetics $[5,6,11]$. High $\mathrm{K}^{+}$leads to cell membrane depolarization, and consequently voltage-gated $\mathrm{Ca}^{2+}$ channels open, transmembrane $\mathrm{Ca}^{2+}$ influx increases, and finally vascular smooth muscle contract. On the other hand, most receptor agonists contract vascular smooth muscles by both eliciting transmembrane $\mathrm{Ca}^{2+}$ influx through corresponding receptor-operated $\mathrm{Ca}^{2+}$ channels and mobilizing intracellular $\mathrm{Ca}^{2+}$ from intracellular $\mathrm{Ca}^{2+}$ stores [9]. The present study shows that ketamine decrease both $\mathrm{KCl}$ - and histamine-evoked contractions. The relaxant effect of ketamine on $\mathrm{KCl}$ - and 
histamine-evoked contractions may be due to the following two mechanisms 1) indirect inhibition of $\mathrm{Ca}^{2+}$ influx following the activation of $\mathrm{K}^{+}$channels and 2) direct inhibition of $\mathrm{Ca}^{2+}$ influx. A probable site of action is $\mathrm{K}^{+}$channels; an increase in $\mathrm{K}^{+}$current hyperpolarizes the membrane. $\mathrm{K}^{+}$channels play an essential role in regulating vascular tone $[10,16]$. Ketamine mediates the activation of both $\mathrm{BK}_{\mathrm{Ca}}$ channels in the porcine coronary artery [4], and ATP-sensitive $\mathrm{K}^{+}\left(\mathrm{K}_{\mathrm{ATP}}\right)$ channels in the rat mesenteric artery and canine pulmonary artery $[3,17]$. On the other hand, some reported that ketamine blocks voltage gated $\mathrm{K}^{+}\left(\mathrm{K}_{\mathrm{v}}\right)$ channels) in rat mesenteric arteries and $\mathrm{K}_{\mathrm{ATP}}$ in rat myocardium $[18,19]$. These data suggest that the subtypes of $\mathrm{K}^{+}$channels involved in ketamine-mediated relaxation of arteries appear to be both tissue- and species-dependent. However, subtypes of $\mathrm{K}^{+}$channels involved in ketamine-mediated relaxation are not fully understood. In the present study, ketamine-induced relaxation was significantly reduced either by TEA, non-specific $\mathrm{K}^{+}$channel blocker, or by iberiotoxin, an inhibitor of $\mathrm{BK}_{\mathrm{Ca}}$ channels. On the other hand, ketamine-induced relaxation was not affected either by 4-AP, a specific inhibitor of $\mathrm{K}_{v}$ channels, or by glibenclamide, a specific inhibitor of $\mathrm{K}_{\text {АтP }}$ channels, suggesting that $\mathrm{K}_{\mathrm{v}}$ or $\mathrm{K}_{\text {АTP }}$ channels are not involved in ketaminemediated relaxation of the rabbit renal artery. Since TEA and iberiotoxin inhibits $\mathrm{BK}_{\mathrm{Ca}}$ channels, this leads to the conclusion that $\mathrm{BK}_{\mathrm{Ca}}$ channels are likely to play a role in ketamine-induced relaxation. Taken together, these data clearly indicate that in the rabbit renal artery, the $\mathrm{BK}_{\mathrm{Ca}}$ channels are involved in ketaminemediated, NO-independent relaxation.

In smooth muscles, the agonist-induced elevation of $\left[\mathrm{Ca}^{2+}\right]_{\mathrm{cyt}}$ was due to the following: 1) activation of $\mathrm{Ca}^{2+}$ influx, 2) activation of $\mathrm{Ca}^{2+}$ release from sarcoplasmic reticulum (SR), and 3) inhibition of $\mathrm{Ca}^{2+}$ sequestration into intracellular stores [9]. The vasorelaxation of ketamine is believed to be mediated by inhibiting both $\mathrm{Ca}^{2+}$ influx, through L-type $\mathrm{Ca}^{2+}$ channels, and $\mathrm{Ca}^{2+}$ release from the internal $\mathrm{Ca}^{2+}$ stores $[9,20]$. However, in some vascular smooth muscles, ketamine had no significant on calcium intake into intracellular stores or on calcium extrusion $[21,22]$. Since there were no differences in the degree of ketamine-induced relaxation in the absence and presence of either ryanodine or thapsigargin, it suggests the possibility that ketamine caused vasodilation in isolated rabbit renal arteries without involvement of $\mathrm{Ca}^{2+}$ release from internal stores. Further investigation of ketamine actions at subcellular levels will enhance our understanding of the relaxant properties.

Another aspect investigated in the present study was whether ketamine-induced vasorelaxation was related to inhibition of $\mathrm{Ca}^{2+}$ influx from the extracellular medium. Ketamine relaxed preparations precontracted with $\mathrm{KCl}$ or histamine in a concentration-dependent manner. It also inhibited $\mathrm{Ca}^{2+}$-induced contractions in $\mathrm{Ca}^{2+}$-free mediums containing high $\mathrm{K}^{+}$. In vascular smooth muscles, ketamine inhibits L-type $\mathrm{Ca}^{2+}$ channels, and reduces $\mathrm{Ca}^{2+}$ influx [20-24]. Taken together, these results support that ketamine can block $\mathrm{Ca}^{2+}$ influx through $\mathrm{Ca}^{2+}$ channels presented in the vascular smooth muscles.

In summary, the results indicated that in the rabbit renal artery, ketamine inhibited both KCl-and histamine-evoked contractions. Ketamine may evoke activation of $\mathrm{BK}_{\mathrm{Ca}}$ channels and thereby inhibit voltage-gated $\mathrm{Ca}^{2+}$ influx in a prolonged manner.

\section{References}

1. Kreuscher H, Gauch H. The effect of phencylidine derivatives ketamine (CI 581) on the cardiovascular system of the man. Anaesthesist 1967; 16: 229-33.

2. Ibeawuchi CU, Ajayi OI, Ebeigbe AB. Vascular effect of ketamine in isolated rabbit aortic smooth muscle. Niger J Physiol Sci 2008; 23: 85-8.

3. Akata T, Izumi K, Nakashima M. Mechanisms of direct inhibitory action of ketamine on vascular smooth muscle in mesenteric resistance arteries. Anesthesiology 2001; 95: 452-62.

4. Klockgether-Radke AP, Huneck S, Meyberg S, Neumann P, Hellige G. Ketamine enantiomers differentially relax isolated coronary artery rings. Eur J Anaesthesiol 2005; 22: 215-21.

5. Lee TS, Hou X. Vasoactive effects of ketamine on isolated rabbit pulmonary arteries. Chest 1995; 107:1152-5.

6. Dojo M, Kinoshita H, Iranami H, Nakahata K, Kimoto Y, Hatano Y. Ketamine steroselectively affects vasorelaxation mediated by ATPsensitive $\mathrm{K}^{+}$channels in the rat aorta. Anesthesiology 2002; 97: 8826.

7. Pabelick CM, Jones KA, Street K, Lorenz RR, Warner DO. Calcium concentration-dependent mechanisms through which ketamine relaxes canine airway smooth muscle. Anesthesiology 1997; 86: 1104-11.

8. Han J, Kim N, Joo H, Kim E. Ketamine blocks Ca2 ${ }^{+}$-activated $\mathrm{K}^{+}$ channels in rabbit cerebral arterial smooth muscle cells. Am J Physiol Heart Circ Physiol 2003; 285: H1347-55.

9. van Breemen C, Saida K. Cellular mechanisms regulating $[\mathrm{Ca} 2+] \mathrm{i}$ smooth muscle. Annu Rev Physiol 1989; 51: 315-29.

10. Ratz PH, Callahan PE, Lattanzio FA Jr. Ketamine relaxes rabbit femoral arteries by reducing [Ca2+]i and phospholipase $\mathrm{C}$ activity. Eur J Pharmacol 1993; 236: 433-41.

11. Ding X, Murray PA. The differential effects of intravenous anesthetics on myofiament $\mathrm{Ca}^{2+}$ sensitivity in pulmonary venous smooth muscle. Anesth Analg 2007; 105: 1278-86.

12. Booke M, Armstrong C, Hinder F, Conroy B, Traber LD, Trabel DL. The effects of propofol on hemodynamics and renal blood flow in healthy and in septic sheep and combined with fentanyl in septic sheep. Anesth Analg 1996; 82: 738-43.

13. Shiga Y, Minami K, Uezono Y, Segawa K, Nagaoka E, Shiraishi $M$, et al. Effects of the intravenously administrated anaesthetics ketamine, propofol and thiamyol on the cortical renal blood flow in rats. Pharmacology 2003; 68: 17-23.

14. Park SY, Jung I, Kwon SC. Mechanism of vasodilation by propofol in the rabbit renal artery. Anesth Pain Med 2011; 6: 336-41. 
15. Chien CT, Cheng YJ, Chen CF, Chen CY, Lin CJ. Differentiation of ketamine effects on renal nerve activity and renal blood flow in rats. Acta Anaesthesiol Taiwan 2004; 42: 185-9.

16. Sobey CG. Potassium channel function in vascular disease. Arterioscler Thromb Vasc Biol 2001; 21: 28-38.

17. Sohn JT, Murray PA. Inhibitory effects of etomidate and ketamine on adenosine triphosphate-sensitive potassium channel relaxation in canine pulmonary artery. Anesthesiology 2003; 98: 104-13.

18. Kim SH, Bae YM, Sung DJ, Park SW, Woo NS, Kim B, et al. Ketamine blocks voltage-gated $\mathrm{K}^{+}$channels and causes membrane depolarization in rat mesenteric artery myocytes. Pflugers Arch 2007; 454: 891-902.

19. Ko SH, Lee SK, Han YJ, Choe H, Kwak YG, Chae SW, et al. Blockade of myocardial ATP-sensitive potassium channels by ketamine. Anesthesiology 1997; 87: 68-74.
20. Kang BS, Lee YH, Nam TS, Yeon DS, Hwang SK, Park KS. Effects of ketamine on contractile responses in vascular smooth muscle. Yonsei Med J 1990; 31: 325-32.

21. Kanmura Y, Missiaen L, Casteels R. The effects of ketamine on $\mathrm{Ca}^{+}$ movements in A7r5 vascular smooth muscle cells. Anesth Analg 1996; 83: 1105-9.

22. Kanmura Y, Yoshitake J, Casteels R. Ketamine-induced relaxation in intact and skinned smooth muscles of the rabbit ear artery. Br J Pharmacol 1989; 97: 591-7.

23. Abdalla SS, Laravuso RB, Will JA. Mechanisms of the inhibitory effect of ketamine on guinea pig isolated main pulmonary artery. Anesth Analg 1994; 78: 17-22.

24. Akata T, Izumi K, Nakashima M. Mechanisms of direct inhibitory action of ketamine on vascular smooth muscle in mesenteric resistance arteries. Anesthesiology 2001; 95: 452-62. 